\title{
Combining Human and Rat Sequences in Her-2 DNA Vaccines Blunts Immune Tolerance and Drives Antitumor Immunity
}

\author{
Jennifer B. Jacob ${ }^{1}$, Elena Quaglino ${ }^{2}$, Olga Radkevich-Brown ${ }^{1}$, Richard F. Jones ${ }^{1}$, Marie P. \\ Piechocki $^{1}$, Joyce D. Reyes ${ }^{1}$, Amy Weise ${ }^{1}$, Augusto Amici ${ }^{3}$, and Wei-Zen Wei ${ }^{1}$ \\ ${ }^{1}$ Karmanos Cancer Institute, Wayne State University, Detroit, Michigan \\ ${ }^{2}$ Molecular Biotechnology Center, Department of Clinical and Biological Sciences, University of \\ Torino, Torino, Italy \\ ${ }^{3}$ Department of Molecular, Cellular, and Animal Biology, University of Camerino, Camerino, Italy
}

\begin{abstract}
Immune tolerance to tumor-associated self-antigens poses a major challenge in the ability to mount an effective cancer vaccine response. To overcome immune tolerance to HER-2, we formulated DNA vaccines that express both human HER-2 and heterologous rat Neu sequences in separate plasmids or as single hybrid constructs that encode HER-2/Neu fusion proteins. Candidate vaccines were tested in Her-2 transgenic (Tg) mice of BALB/c (BALB), BALB/c $\times$ C57BL/6 F1 (F1), or C57BL/6 (B6) background, which exhibit decreasing immune responsiveness to HER-2. Analysis of various cocktails or hybrid vaccines defined a requirement for particular combination of HER/2/Neu sequences to effectively prime immune effector cells in HER-2 Tg mice. In B6 HER-2 Tg mice, rejection of HER-2-positive tumors protected mice from HER-2-negative tumors, providing evidence of epitope spreading. Our findings show that a strategy of combining heterologous antigen with self-antigens could produce a potent DNA vaccine that may be applicable to other tumor-associated antigens.
\end{abstract}

\section{Introduction}

Dysregulated signal transduction from overexpressed or mutated ErbB-2 (Her-2/neu) leads to cellular immortalization, neoplastic transformation, and tumor progression $(1,2)$. Consequently, Her-2 is a negative prognostic factor in breast cancer (3-6). Monoclonal antibodies (mAb) such as trastuzumab (Herceptin) and receptor tyrosine kinase inhibitors such as lapatinib are effective against Her-2-positive breast cancers (7-9), but patients typically develop resistance after treatment, suggesting compensatory activity through alternative signaling pathways (10-13).

Her-2 DNA vaccines have shown promising activities in human Her-2 or rat neu transgenic ( Tg) mice, but immune tolerance to tumor-associated self-antigens continues to be a major challenge $(14,15)$. In several experimental autoimmune disease models, tolerance to self-

\footnotetext{
(C) 2010 American Association for Cancer Research.

Corresponding Author: Wei-Zen Wei, Karmanos Cancer Institute, Wayne State University, 110 East Warren Avenue, Detroit, MI 48201. Phone: 313-578-4651; Fax: 313-578-4658; weiw @karmanos.org.

Note: Supplementary data for this article are available at Cancer Research Online (http://cancerres.aacrjournals.org/).

Requests for plasmids pE2-Neutm (HuRT) and pNeu-E2тм (RHuT) should be directed to Augusto Amici, augusto.amici@unicam.it. Disclosure of Potential Conflicts of Interest

W-Z. Wei: consultant/advisory board, NIH and Department of Defense. The other authors disclosed no potential conflicts of interest.
} 
antigens is overcome by immunization with heterologous (xenogeneic) antigens, e.g., murine experimental autoimmune encephalomyelitis is induced by bovine or guinea pig myelin basic protein $(16,17)$, collagen-induced arthritis by bovine, porcine, or human collagen (18), and autoimmune myasthenia gravis by Torpedo californica acetylcholine receptor $(19,20)$. These heterologous antigens may share common or cross-reactive epitopes with self-antigens to overcome immune tolerance and trigger self-reactive $\mathrm{T}$ cells. Importantly, human or mouse tyrosinase DNA prolongs the survival of dogs with malignant melanoma (21), resulting in the licensing of a DNA vaccine for canine melanoma $(21,22)$.

To test if heterologous antigens could be exploited to improve Her-2 vaccine efficacy, BALB NeuT mice expressing a rat neu transgene were electrovaccinated with human Her-2 or self neu DNA (23). Greater T-cell response to neu was induced by heterologous Her-2 than by self neu. But only self neu, not heterologous Her-2 vaccine, induced the anti-neu antibodies that were critical in delaying spontaneous tumor formation. These results reflect the exquisite specificity of anti-neu antibodies and that humoral immunity is the primary effector mechanism against neu-induced spontaneous tumors. Not all Her-2-positive breast cancers are sensitive to antibody-mediated destruction (24). Wehave shown that TUBO and Bam1a cells, established from BALB NeuT spontaneous mammary tumors, were highly sensitive to anti-neu $\mathrm{mAb}$ or receptor tyrosine kinase inhibitor. On the other hand, receptor tyrosine kinase inhibitor-resistant BamIR-5 or neu-transfected D2F2/neu cell lines were refractory to antibody therapy. Nevertheless, all test cells could be controlled by CTL, demonstrating the importance of inducing both T-cell and B-cell responses with Her-2 vaccines (24). In this study, we tested the hypothesis that cocktail or hybrid vaccines containing both self human Her-2 and heterologous rat neu DNA sequences would induce greater antitumor immunity than either single antigen.

We have shown that human Her-2 Tg mice on a BALB/c background were much more responsive to Her-2 vaccination than those on a C57BL/6 background (15). Therefore, the candidate vaccines were tested in Her-2 Tg mice of BALB/c, C57BL/6, or (BALB/c $\times$ C57BL/6) F1 background to represent patients with heterogeneous genetic makeup.

\section{Materials and Methods}

\section{Mice}

All animal procedures were conducted in accordance with accredited institution guidelines and the U.S. Public Health Service Policy on Humane Care and Use of Laboratory Animals. C57BL/6 (B6) and BALB/c (BALB) female mice were purchased from Charles River Laboratory. Heterozygous C57BL/6 Her-2 Tg mice (B6 Her-2 Tg), which expressed the full-length, wild-type human Her-2 under the whey acidic protein promoter were generated in our laboratory and have been maintained by mating with wild-type B6 mice (25). BALB/c Her-2 Tg (BALB Her-2 Tg) mice were generated by back-crossing B6 Her-2 Tg mice with wild-type BALB/c mice (15). (BALB $\times$ B6) F1 Her-2 Tg mice $(\mathrm{F} 1 \mathrm{Her}-2 \mathrm{Tg})$ were generated by crossing BALB Her-2 Tg mice with wild-type B6 mice or vice versa. Transgene-positive mice were identified by PCR as we previously described (25).

\section{DNA vaccine constructs}

pVax/E2 $2_{\text {тм }}\left(\mathrm{pE} 22_{\mathrm{Tм}}\right)$ and pcDNA/ Neuтм (рNeuтм) encoding the extracellular and transmembrane domains of human (Her-2) or rat (neu) erbB-2, respectively, have been previously described (23). pEFBos/granulocyte macrophage colony-stimulating factor (pGM-CSF) encoding murine GM-CSF was provided by Dr. N. Nishisaki at Osaka University, Osaka, Japan. The blank vector, pVax1 (Invitrogen), was the control. 
Hybrid DNA vaccines pE2-Neuтм (alternatively designated as HuRT in EP08004513.1 and manuscript submitted by Quaglino and colleagues), pNeuE2 2 (alternatively designated as RHuT in USP20070299023 and manuscript submitted by Quaglino and colleagues), and pE2-Neu ${ }_{500}$ тм were generated (Fig. $1 A$ ), using strategies described in Supplementary Fig. S1.

\section{Characterization of DNA constructs}

DNA constructs were transiently transfected into 3T3 cells using LipofectAMINE 2000 (Invitrogen) following the instructions of the manufacturer. The mAb TA-1 (Ab5; Calbiochem), N12, N29 (both hybridomas provided by Dr. Yosef Yarden, Weissman Institute; refs. 26, 27), and trastuzumab (Genentech; ref. 28) were used to characterize Her-2 epitopes in the chimera fusion protein and 7.16.4 (Ab4, Calbiochem) for the neu epitope (29). Polyclonal Her-2 and neu immune sera were used as positive controls. PE-goat antimouse IgG or PE-mouse anti-human IgG was the secondary antibody. Samples were analyzed on a BD FACScalibur or FACScanto II and with FlowJo software (TreeStar).

\section{Cell lines}

The BALB/c mouse mammary tumor line D2F2 was established in our group from a spontaneous tumor that arose from the prolactin-induced hyperplastic alveolar nodule line, $\mathrm{D} 2$, as previously described (30). D2F2/E2 was generated by stable transfection of D2F2 cells with wild-type human Her-2 $(23,31)$. Their mouse origin was verified by spectral karyotyping in 2008 (24). E0771/E2 provided by Dr. Daniel Allendorf in 2005 (James Graham Brown Cancer Center, Louisville, KY) was generated by transfecting the C57BL/6 mammary tumor E0771 with wild-type Her-2 (15). E0771 and E0771/E2 developed into palpable tumors in mice of C57BL/6 origin. BALB/c antigen-presenting cells 3T3/KB expressed $\mathrm{H} 2 \mathrm{~K}^{\mathrm{d}}$ and $\mathrm{B} 7.1(\mathrm{CD} 80)$, and 3T3/EKB or 3T3/ NKB expressed additional Her-2 or neu $(23,32)$. C57BL/6 TC-1 cells (Dr. T.C. Wu, The Johns Hopkins University, Baltimore, MD) expressed endogenous $\mathrm{H} 2 \mathrm{~K}^{\mathrm{b}}$ and B7.1 (15). TC-1/E2 was transfected to express wild-type Her-2 as antigen-presenting cells. SKOV3, a human ovarian cancer cell line with amplified Her-2 (33), was purchased from American Type Culture Collection and Her-2 expression was verified regularly by flow cytometry. The hybridoma line PC61 (American Type Culture Collection), which produces rat mAb to mouse CD25 was propagated in severe combined immunodeficient mice. All cell lines were maintained as previously described (34).

\section{Immunization}

Mice received DNA electrovaccination as we previously described (34). Wild-type mice were immunized twice whereas Her-2 $\mathrm{Tg}$ mice were immunized four times. To deplete $\mathrm{CD} 25^{\mathrm{hi}}$ regulatory $\mathrm{T}$ cells (Treg), indicated groups of mice received $0.5 \mathrm{mg}$ of CD25 mAb, PC61, i.p. $7 \mathrm{~d}$ prior to the first electrovaccination. Depletion of CD25 ${ }^{\text {hi }} \mathrm{T}$-cells was verified by flow cytometry.

\section{Measurement of Her-2 or neu binding antibodies by flow cytometry}

Anti-Her-2 antibodies were measured by binding to Her-2 overexpressing SKOV3 cells using flow cytometry, and antibody concentrations were calculated by regression analysis using mAb TA-1 as the standard (35). Normal mouse serum or isotype-matched $\mathrm{mAb}$ was the negative control. Antineu antibody was measured with 3T3/NKB cells (Jackson ImmunoResearch) and the standard curve was generated using mAb 7.16.4 (Ab4). Differences in antibody concentration were analyzed by Student's $t$ test. IgG isotypes were measured with FITC-conjugated goat anti-mouse $\operatorname{IgG}_{1}$ or $\operatorname{IgG}_{2 \mathrm{a}}$ (Jackson ImmunoResearch) and expressed as mean channel fluorescence. 


\section{Measurement of T-cell response by IFN-y ELISPOT}

All ELISPOT reagents were purchased from BD Biosciences, unless otherwise specified. Her-2-reactive T cells were enumerated by IFN- $\gamma$ ELISPOT assay as we described $(15,23)$. Peripheral blood (PBL) or spleen cells were incubated for $48 \mathrm{~h}$ with the antigen-presenting cells TC-1, TC-1/E2, 3T3/KB, or 3T3/EKB at an antigen-presenting cell/lymphocyte ratio of 1:10. The results were expressed as the number of cytokine-producing cells per $10^{6} \mathrm{PBL}$ or spleen cells. Neu-reactive T cells were monitored using 3T3/NKB cells as antigenpresenting cells. Data were analyzed using Student's $t$ test.

\section{Tumor growth inhibition assay}

To measure protective immunity, Her- $2 \mathrm{Tg}$ mice were inoculated s.c. in the flank with $2 \times$ $10^{5} \mathrm{D} 2 \mathrm{~F} 2 / \mathrm{E} 2$ or E0771/E2 tumor cells 2 wk after the fourth electrovaccination. Tumor growth was monitored weekly, and tumor volume was calculated by $X Y^{2} / 2(X=$ long axis, $Y=$ short axis). To test therapeutic potential, mice were inoculated with $2 \times 10^{5} \mathrm{D} 2 \mathrm{~F} 2 / \mathrm{E} 2$ or E0771/E2 tumor cells $11 \mathrm{~d}$ after a single vaccination. B6 Her-2 Tg mice were depleted of Treg using $0.5 \mathrm{mg}$ of PC61 $7 \mathrm{~d}$ prior to the first electrovaccination. Starting $3 \mathrm{~d}$ following tumor inoculation, mice received three weekly vaccinations. Tumor growth was monitored by weekly palpation and difference in tumor incidence was analyzed by the log rank test.

\section{Results}

\section{Induction of Her-2 immunity with self versus heterologous DNA vaccine}

To compare the activity of self versus heterologous vaccines, BALB NeuT or BALB Her-2 $\mathrm{Tg}$ mice were electrovaccinated four times, every 2 weeks, with $50 \mu \mathrm{g}$ of pE2тм or рNеuтм. In all vaccination experiments, equal amounts of pGM-CSF were coadministered. Antibody response was measured 2 weeks after the final vaccination. As shown in Table 1, pNeuтм induced higher levels of neu binding antibodies when administered as a foreign antigen in Her-2 Tg mice $(54 \pm 5 \mu \mathrm{g} / \mathrm{mL})$ rather than as a self-antigen in NeuT Tg mice $(16 \pm 2 \mu \mathrm{g} /$ $\mathrm{mL}$ ), but neither antiserum recognized Her-2, showing antigen specificity. Similarly, $\mathrm{pE} 2 \mathrm{Tм}$ induced more Her-2-binding antibodies in NeuT $(40 \pm 3 \mu \mathrm{g} / \mathrm{mL})$ than in Her-2 Tg $(20 \pm 5$ $\mu \mathrm{g} / \mathrm{mL}$ ) mice, again neither serum recognized neu. Therefore, antibodies induced by DNA vaccines showed exquisite specificity to the cognate antigen.

In the T-cell compartment, however, heterologous antigen was more effective in activating self-reactive T cells. In NeuT mice, self pNeuтм induced $294 \pm 50$ spots $/ 10^{6}$ spleen cells of neu-specific, IFN- $\gamma$-producing $\mathrm{T}$ cells, but heterologous $\mathrm{pE} 2$ тм activated more anti-neu $\mathrm{T}$ cells at $567 \pm 176$ ( P < 0.001). Similarly, in Her-2 Tg mice, heterologous pNeuтм induced $292 \pm 16$ anti-Her-2 T cells, significantly more than that by self $\mathrm{pE} 2 \mathrm{тм}(124 \pm 4, P<0.001)$. Therefore, heterologous Her-2 or neu DNA is superior in overcoming T-cell tolerance. All ELISPOT assays were performed with pooled PBL except in NeuT mice whose splenocytes were used because neu-reactive T cells were not detectable in their PBL.

\section{Induction of Her-2 immunity with a cocktail vaccine of pE2}

The disparate cellular and humoral immunity induced by heterologous and self-antigens led to the hypothesis that antitumor immunity may be enhanced by combined vaccination with rat neu and human Her-2. To test this hypothesis, BALB Her-2 Tg mice were immunized four times with a cocktail of $25 \mu \mathrm{g}$ of $\mathrm{pE} 2$ тм and $25 \mu \mathrm{g}$ of pNeuтм (Fig. 1). Control groups received $50 \mu \mathrm{g}$ of either pNеuтм or $\mathrm{pE} 2$ тм. The cocktail vaccine induced $74 \pm 9 \mu \mathrm{g} / \mathrm{mL}$ of Her-2 binding antibodies at week 8, compared with $23 \pm 17 \mu \mathrm{g} / \mathrm{mL}$ by $\mathrm{pE} 2$ тм alone, showing significant amplification of humoral response by the presence of heterologous neu in the vaccine (Fig. $1 B$ ). In the T-cell compartment, pE2тм activated more T cells than 
heterologous pNeuтм after two vaccinations (Fig. 1C). After four vaccinations, T-cell response in рNеuтм immunized mice escalated to reach $292 \pm 16 / 10^{6} \mathrm{PBL}$, whereas the $\mathrm{pE} 2$ тм immunized mice produced $116 \pm 21 / 10^{6} \mathrm{PBL}$. Surprisingly, T-cell response in the cocktail vaccine group was only comparable to that in $\mathrm{pE} 2$ тм group, below that induced by the heterologous pNeuтм. Because pNeuтм itself did not induce Her-2-binding antibodies (Table 1; ref. 23) and Her-2- specific T-cell response was not elevated by the cocktail vaccine (Fig. 1C), the enhanced Her-2 antibody response could be due to immune stimulation by the foreign epitopes in neu.

All test and control mice were challenged s.c. with D2F2/ E2 tumor cells (Fig. 1D), which were rejected in $72 \%$ (five of seven) of mice receiving the pE2 compared with $38 \%$ (three of eight) in the $\mathrm{pE} 2$ тм group $(P<0.05)$ and $60 \%(6$ of 10$)$ in the pNeuтм group. The elevated levels of Her-2 antibodies induced by the cocktail vaccine might mediate antibody-dependent cell-mediated cytotoxicity to exert greater inhibition of tumor growth even though D2F2/E2 tumor cells are insensitive to the direct inhibitory effects of Her-2 antibodies (24). Importantly, pNeuтм, which induced strong T-cell response without anti-Her-2 antibody, showed comparable antitumor activity to the cocktail vaccine. 2

\section{Generation and characterization of hybrid Her-2-neu vaccines}

Because antibody-sensitive and -resistant cells both exist in human breast cancer, the efficacy of combining Her-2 and neu into one vaccine formulation was further tested with hybrid vaccines that encode fusion proteins of Her-2 and neu (Fig. 1A; Supplementary Fig. $\mathrm{S} 1)$. The chimeric E2-Neuтм protein is a transmembrane Her-2-neu fusion protein with a truncated ICD. Neu-E2 2 м is the reverse product with neu at the $\mathrm{NH}_{2}$ terminus and Her-2 at the $\mathrm{COOH}$ terminus (36). The third chimeric vaccine $\mathrm{pE} 2-\mathrm{Neu}_{500^{\mathrm{TM}}}$ was modified from $\mathrm{pE} 2-$ Neuтм to restore Her-2 amino acids 501 to 687 which encompassed the epitope(s) recognized by trastuzumab (28). The fusion protein generated from each test construct was verified after transient transfection into $3 \mathrm{~T} 3$ cells, using a panel of Her-2 and neu mAbs as well as polyclonal antibodies (Supplementary Fig. S1).

Immunogenicity of the hybrid vaccines was verified in wild-type BALB/c females. Comparable levels of Her-2 antibodies $(\sim 40 \mu \mathrm{g} / \mathrm{mL})$ were induced by pE2тм, pE2-Neuтм, and pE2-Neu ${ }_{500^{\mathrm{TM}}}$ (Supplementary Fig. S2A), each containing Her-2 $\mathrm{NH}_{2}$-terminal codons. pNeu-E2 2 тм containing $\mathrm{NH}_{2}$-terminal neu induced less Her-2 binding antibodies at $18 \pm 4 \mu \mathrm{g}$ / $\mathrm{mL}$. pNeuтм did not induce Her-2 binding antibodies as predicted (Table 1). Conversely, $\sim 70 \mu \mathrm{g} / \mathrm{mL}$ of neu-binding antibodies were induced by рNеuтм or pNeu-E2тм, which contained neu in the $\mathrm{NH}_{2}$ terminus (Supplementary Fig. S2A) with low-level activity from pE2-Neuтм or pE2-Neu ${ }_{500^{\mathrm{TM}}}(11 \pm 3$ and $6.3 \pm 3 \mu \mathrm{g} / \mathrm{mL}$, respectively). Therefore, in wildtype mice, fusion proteins which contained Her- 2 or neu in the $\mathrm{NH}_{2}$ terminus induced greater antibody response to the respective antigen.

Regarding T cells, high levels of Her-2-specific IFN- $\gamma$ - secreting cells were induced by pE2 2 ом or pE2-Nеuтм and modestly by pNeuтм or pNeu-E2тм (Supplementary Fig. S2B). Neuspecific T-cell response was comparable in mice vaccinated with pNeuтм, pNeu-E2тм, or $\mathrm{pE} 2 \mathrm{\tau м}$, with somewhat weaker response from $\mathrm{pE} 2-\mathrm{Neu} \mathrm{тм}$. Bearing some variation, hybrid vaccines were immunogenic in wild-type mice, with the $\mathrm{NH}_{2}$ terminus sequences of Her-2 showing greater immunogenicity.

\section{Activity of hybrid vaccines in Her-2 Tg mice}

BALB Her-2 Tg mice-The immunogenicity and efficacy of hybrid vaccines were tested in BALB Her-2 Tg mice using pE2-Nеuтм or the reverse pNeu-E2 2 м. pE2тм was the control. 
pE2-Neuтм induced significantly higher levels of Her-2 antibodies, compared with pE2тм or pNeu-E2тм, more prominently after the third vaccination (Fig. 2A), consistent with greater immunogenicity of epitopes in Her- $2 \mathrm{NH}_{2}$ terminus. Immunoglobulin isotype analysis showed the induction of both $\operatorname{IgG}_{1}$ and $\operatorname{IgG}_{2 \mathrm{a}}$ (Fig. $2 A$, right).

Her-2-reactive T cells in pooled PBL were measured after two and four vaccinations (Fig. $2 B$ ). After two vaccinations, $\mathrm{pE} 2$ тм induced more IFN- $\gamma$-secreting $\mathrm{T}$ cells than either hybrid constructs. After four vaccinations with $\mathrm{pE} 2-\mathrm{Neu}$ тм, however, hybrid $\mathrm{pE} 2-\mathrm{Neu}$ тм showed a modest edge over pE2 $2_{\text {тм }}\left(153 \pm 4 / 10^{6}\right.$ compared with $\left.116 \pm 21 / 10^{6}\right)$ and pNeu-E2 $2_{\text {тм }}(92 \pm$ $4 / 10^{6}$ ), suggesting the advantage of concurrent presentation of neu and preservation of Her-2 $\mathrm{NH}_{2}$ terminus in the vaccine regimen.

When mice were challenged subcutaneously with D2F2/ E2 cells, $80 \%$ (8 of 10) of pE2Neuтм-vaccinated mice were protected, but only $40 \%$ of $\mathrm{pE}_{\mathrm{T}} \mathrm{T}_{\mathrm{M}^{-}}$-vaccinated mice ( 2 of 5) and 33\% (3 of 9) of pNeu-E2 $2 \mathrm{TM}-\mathrm{vaccinated}$ mice were protected (Fig. 2C). Thus, enhanced Her-2 antibody and T-cell response was induced after four vaccinations with hybrid pE2Nеuтм to result in elevated antitumor activity.

\section{(BALB $\times$ B6) F1 Her-2 Tg mice}

We previously reported that BALB Her-2 Tg mice were much more responsive to $\mathrm{pE} 2 \mathrm{TM}$ than B6 Her-2 Tg mice, and that (BALB $\times$ B6) F1 Her-2 Tg mice produced intermediate response $(15,25)$. To further test the efficacy of hybrid vaccines, F1 Her-2 Tg mice which showed intermediate Her-2 reactivity were immunized with $\mathrm{pE} 2$ тм, $\mathrm{pE} 2-\mathrm{NeuTM}$, or pE2$\mathrm{Neu}_{500^{\mathrm{T}}}$, the latter was constructed to restore Her-2 amino acids 501 to 650, thus reintroducing the epitopes recognized by trastuzumab and reducing the neu sequence from 263 amino acids to 110 amino acids. In some test mice, Treg were depleted with CD25 mAb 1 week before vaccination (Fig. 3A; ref. 15).

In mice with intact Tregs, Her-2 antibodies induced by pE2-Nеuтм more than doubled that by $\mathrm{pE} 2$ тм or $\mathrm{pE} 2-\mathrm{Neu}_{500^{\mathrm{TM}}}$ (Fig. 3B, left). After Treg depletion, antibody response increased most significantly in the pE2-Neu $500^{\mathrm{TM}}$ group to approach that by pE2-Neuтм (Fig. 3B, right). These results suggested that Her-2 extracellular domain residues 500 to 687 may activate Treg and their presence in $\mathrm{pE} 2-\mathrm{Neu}_{500^{\mathrm{TM}}}$ might compromise vaccine activity.

After four vaccinations, pE2-Nеuтм induced significantly more IFN- $\gamma$-producing T cells

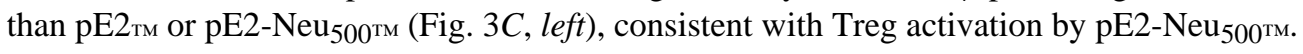
Furthermore, the shorter 110 residues of heterologous neu in $\mathrm{pE} 2-\mathrm{Neu}_{500^{\mathrm{T}}}$ may be insufficient to overcome Her-2 tolerance. After Treg depletion, T-cell response in every group increased; still, pE2-Neuтм induced more than twice the number of IFN- $\gamma$-producing T cells $(397 \pm 30)$ than $\mathrm{pE} 2$ тм $(147 \pm 15)$. T-cell response to $\mathrm{pE} 2-\mathrm{Neu}_{500^{\mathrm{TM}}}$ improved, but did not approach pE2-Neuтм, indicating the need for additional neu residues for Her-2 T-cell activation (Fig. 3C).

To measure antitumor immunity, the experiment was repeated with an increased number of mice. Treg-depleted F1 Her-2 Tg mice were vaccinated four times with pE2-Neuтм, $\mathrm{pE} 2$ тм, or control pVax1 before they were inoculated s.c. with Her-2-transfected D2F2/E2 cells of $\mathrm{BALB} / \mathrm{c}$ origin or E0771/ $\mathrm{E} 2$ cells of C57BL/6 origin. There were six to seven mice in each group. All tumors grew progressively in pVax1 control mice (Fig. 3D). pE2тм vaccination protected six of seven mice from D2F2/E2 and five of seven mice from E0771/E2. In the pE2-Neuтм-vaccinated group, all mice rejected the challenging tumor, either D2F2/E2 or E0771/E2. Therefore, the hybrid pE2-Neuтм induced stronger humoral and cellular immunity than $\mathrm{pE} 2$ тм in F1 Her-2 Tg mice to provide complete protection from tumors of either parental background. 


\section{B6 Her-2 Tg mice}

pE2-Neuтм was further tested in B6 Her-2 Tg mice which were poorly responsive to $\mathrm{pE} 2 \mathrm{Tм}$ vaccination $(15,23)$. Treg were depleted with $\mathrm{CD} 25 \mathrm{mAb} 1$ week before mice were vaccinated with $\mathrm{pE} 2-\mathrm{Neu}$ тм or control $\mathrm{pE} 2$ тм.

After a single vaccination, pE2-Nеuтм already induced significantly more Her-2-binding antibodies than $\mathrm{pE} 2$ тм. After four vaccinations, $\mathrm{pE} 2$-Neuтм induced $64 \pm 4 \mu \mathrm{g} / \mathrm{mL}$ of Her-2 antibodies and pE2 тм induced $20 \pm 9 \mu \mathrm{g} / \mathrm{mL}$ (Fig. 4A). In T-cell response, $\mathrm{pE} 2_{\text {тм }}$ induced 13 \pm 2 IFN- $\gamma$-secreting cells $/ 10^{6} \mathrm{PBL}$, whereas the pE2-Neu $4 B$ ). At 2 weeks after the final vaccination, mice were challenged with $2 \times 10^{5} \mathrm{E} 0771 / \mathrm{E} 2$ cells. In $40 \%$ (two of five) of $\mathrm{pE} 2 \mathrm{TM}_{\mathrm{TM}}$-vaccinated mice and $100 \%$ (five of five) of pE2-Neuтмvaccinated mice, the tumors were rejected, further supporting greater efficacy of the hybrid vaccine (Fig. 4C, left). To determine whether rejection of E0771/E2 resulted in immune priming to other tumor-associated antigens, $\mathrm{pE2}-\mathrm{Neu}_{\mathrm{T}}-\mathrm{vaccinated}$ mice which rejected the primary tumors were re-challenged 7 weeks later with parental E0771 which did not express Her-2 and $80 \%$ (four of five) of these mice rejected the second tumor challenge (Fig. $4 C$, right). Thus, the pE2-Neuтм hybrid overcame Her-2 immune tolerance regardless of their intrinsic level of tolerance to Her-2, inducing tumor rejection while triggering immune priming to additional tumor-associated antigens.

\section{Efficacy of one preventive and three therapeutic vaccinations}

To further test the efficacy of $\mathrm{pE} 2$ тм and $\mathrm{pE} 2$-Nеuтм in more stringent conditions, BALB Her-2 and B6 Her-2 Tg mice were electrovaccinated once before they were inoculated s.c. with D2F2/E2 and E0771/E2 cells, respectively (Fig. 5A). Mice then received three weekly vaccinations following tumor inoculation. In B6 Her-2 Tg mice, Treg were depleted before the first vaccination. Her-2 antibody production was evident after a single vaccination with the hybrid DNA and tumor inoculation. Antibody levels continued to escalate with repeated vaccination (Fig. $5 B$ and $D$, left). In both strains of mice, pE2-Neuтм showed significantly greater immunogenicity than $\mathrm{pE} 2 \mathrm{Tм}$. In BALB Her-2 Tg mice, tumor growth was inhibited by $88 \%$ (pE2-Neuтм) and 70\% (рE2тм), showing that one preventive and three therapeutic vaccines provided significant antitumor immunity. Primary cultures of D2F2/E2 tumor outgrowths were prepared from each test group and Her-2 expression was retained by the outgrowth, whether or not mice were vaccinated.

In B6 Her-2 Tg mice, however, significant rejection of E0771/E2 tumors was not achieved

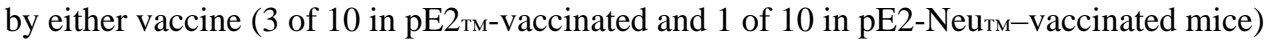
although high levels of Her-2 antibodies were induced by pE2-Nеuтм. However, the average volume of tumors in immunized mice was significantly reduced compared with the $\mathrm{pVax} 1$ group. When primary cultures of E0771/E2 tumors were prepared at week 7, little to no Her-2 expression was detected even in mice which received the $\mathrm{pVax} 1$ control vector. Therefore, loss of Her-2 expression in vivo muted the excellent anti-Her-2 immunity induced by vaccination.

These results showed the efficacy of DNA vaccination against Her-2-expressing tumors when administered as one preventive and three therapeutic vaccines. The vaccine specificity was further illustrated by the rejection of D2F2/ E2 tumors which retained Her-2 expression in vivo, but less so of E0771/E2 tumors, which lost Her-2 expression in vivo.

\section{Discussion}

A new vaccination regimen that presented heterologous rat neu together with self Her-2 in a cocktail or as a hybrid construct significantly improved anti-Her-2 immunity and protective 
activity in Her-2 Tg mice of three different genetic backgrounds. Most notably, seven of eight tumors in BALB Her-2 Tg mice were rejected after one preventive and three therapeutic vaccination with $\mathrm{pE2}-\mathrm{Neu} \mathrm{Tм}$. Antibody response was highly elevated by the cocktail or pE2-Nеuтм hybrid vaccine, even though neu itself did not induce Her-2-binding antibodies, suggesting immune stimulation by the foreign epitopes in neu. On the contrary, heterologous pNeuтм induced significantly more Her-2-reactive T cells than self $\mathrm{pE} 22_{\mathrm{Tм}}$, but elevated T-cell response was evident only after repeated pNеитм immunization, showing a delayed yet eventually more profound T-cell activation by cross-reactive T-cell epitopes from neu. This disparity in antibody and T-cell responses induced by heterologous Her-2/ neu antigen was consistent with our previous report (23).

The $\mathrm{NH}_{2}$ terminus of Her-2 showed greater immunogenicity in both wild-type BALB/c and BALB Her-2 Tg mice, whereas heterologous neu residues 501 to 688 were important in overcoming Her-2 tolerance as both pNeu-E2 2 м or pE2-Neu ${ }_{500^{\mathrm{TM}}}$ lacking neu amino acids 501 to 688 were less effective. After Treg depletion, Her-2 antibody response to pE2$\mathrm{Neu}_{500^{\mathrm{TM}}}$ approached that of pNeu-E2тм and may indicate activation of Treg by Her-2 residues 501 to 687 . Based on these findings, it may be possible to design hybrid vaccines targeting other tumor-associated antigens once the critical regions for immune activation in self and heterologous antigens are defined.

The high level of sequence identity and the similarity in three-dimensional structures of Her-2 and neu enabled the generation of stable fusion proteins E2-Neuтм, E2-Neu ${ }_{500}{ }^{\mathrm{TM}}$, and Neu-E2 2 to facilitate vaccine development. Incorporation of strong foreign epitopes such as tetanus toxin, rather than heterologous neu may also enhance the immune response to Her-2, but without the benefit of shared epitopes. When extrapolating from these findings to new vaccines, the high level of sequence identity between Her-2 and neu (88\%) or between Her-2 and mouse ErbB-2 (84\%) should be noted. It is possible that only a highly homologous sequence from a xenogeneic origin is effective in overcoming self-tolerance.

IFN- $\gamma$-producing T cells can be detected in the PBL of Her-2 Tg mice. It is therefore possible to measure T-cell activity with pooled PBL and monitor tumor growth in the same group of mice. In NeuT mice, IFN- $\gamma$-producing T-cells were not found in the PBL, although they were readily detected in the spleens (Table 1). It is possible that circulating neu-specific $\mathrm{T}$ cells extravagated and localized in the 10 mammary glands which expressed large quantities of neu, and thus, are below detection in PBL.

When pE2-Nеuтм was administered as one preventive followed by three therapeutic vaccinations, D2F2/E2 tumors which retained Her-2 expression in vivo were rejected in seven of eight BALB Her-2 Tg mice, demonstrating the efficacy of DNA vaccine in this more stringent setting. Comparable levels of Her-2 antibodies were induced inB6Her-2Tgmice following the same vaccination regimen after Treg depletion. Although average tumor growth was slowed in $\mathrm{pE} 2-\mathrm{Ne} \mathrm{u}_{\mathrm{TM}}$-immunized mice for several weeks, rejection of the E0771/E2 tumor was poor because these tumor cells lost Her-2 expression in vivo.

Unlike syngeneic mice, humans are heterogeneous in their genetic background. With Her-2 $\mathrm{Tg}$ mice in BALB, B6, and F1 background, variation in immune responses to Her-2 vaccine became evident (15). Using hybrid pE2-Neuтм, even the most tolerant B6 Her-2 Tg mice responded with a striking complete protection from tumor challenge. With one preventive and three therapeutic vaccinations, hybrid pE2-Nеuтм induced significant tumor rejection in BALB Her-2 Tg mice. The concurrent presentation of self and heterologous antigen in a cocktail or in a hybrid construct augmented anti-Her-2 immunity, and thus, should be considered for future vaccine design. 


\section{Supplementary Material}

Refer to Web version on PubMed Central for supplementary material.

\section{Acknowledgments}

The authors thank Drs. Guido Forni and Federica Cavallo for their insightful advice, Serene Lane and Laura Baksic for their excellent care of the experimental animals, and Antoinette Klempay for her meticulous preparation of vaccine plasmids.

Grant Support

NIH CA 76340 and CA 125680 (W-Z. Wei).

\section{References}

1. Hung MC, Lau YK. Basic science of HER-2/neu: a review. Semin Oncol. 1999; 4(suppl 12):51-59. [PubMed: 10482194]

2. Karunagaran D, Tzahar E, Beerli RR, et al. ErbB-2 is a common auxiliary subunit of NDF and EGF receptors: implications for breast cancer. EMBO J. 1996; 15:254-264. [PubMed: 8617201]

3. Pietras RJ, Fendly BM, Chazin VR, Pegram MD, Howell SB, Slamon DJ. Antibody to HER-2/neu receptor blocks DNA repair after cisplatin in human breast and ovarian cancer cells. Oncogene. 1994; 9:1829-1838. [PubMed: 7911565]

4. Ben-Levy R, Paterson HF, Marshall CJ, Yarden Y. A single autophosphorylation site confers oncogenicity to the Neu/ErbB-2 receptor and enables coupling to the MAP kinase pathway. EMBO J. 1994; 13:3302-3311. [PubMed: 7913890]

5. Slamon DJ, Godolphin W, Jones LA, et al. Studies of the HER-2/neu proto-oncogene in human breast and ovarian cancer. Science. 1989; 244:707-712. [PubMed: 2470152]

6. Kiessling R, Wei WZ, Herrmann F, et al. Cellular immunity to the Her-2/neu protooncogene. Adv Cancer Res. 2002; 85:101-144. [PubMed: 12374283]

7. Pegram MD, Lipton A, Hayes DF, et al. Phase II study of receptor-enhanced chemosensitivity using recombinant humanized anti-p185HER2/neu monoclonal antibody plus cisplatin in patients with HER2/neu-overexpressing metastatic breast cancer refractory to chemotherapy treatment. J Clin Oncol. 1998; 16:2659-2671. [PubMed: 9704716]

8. Pegram MD, Konecny GE, O'Callaghan C, Beryt M, Pietras R, Slamon DJ. Rational combinations of trastuzumab with chemotherapeutic drugs used in the treatment of breast cancer. J Natl Cancer Inst. 2004; 96:739-749. [PubMed: 15150302]

9. Rusnak DW, Affleck K, Cockerill SG, et al. The characterization of novel, dual ErbB-2/EGFR, tyrosine kinase inhibitors: potential therapy for cancer. Cancer Res. 2001; 61:7196-7203. [PubMed: 11585755]

10. Ritter CA, Perez-Torres M, Rinehart C, et al. Human breast cancer cells selected for resistance to trastuzumab in vivo overexpress epidermal growth factor receptor and ErbB ligands and remain dependent on the ErbB receptor network. Clin Cancer Res. 2007; 13:4909-4919. [PubMed: 17699871]

11. Cameron D, Casey M, Press M, et al. A phase III randomized comparison of lapatinib plus capecitabine versus capecitabine alone in women with advanced breast cancer that has progressed on trastuzumab: updated efficacy and biomarker analyses. Breast Cancer Res Treat. 2008; 112:533-543. [PubMed: 18188694]

12. Wang SE, Shin I, Wu FY, Friedman DB, Arteaga CL. HER2/Neu (ErbB2) signaling to Rac1-1 is temporally and spatially modulated by transforming growth factor $\beta$. Cancer Res. 2006; 66:95915600. [PubMed: 17018616]

13. Valabrega G, Montemurro F, Aglietta M. Trastuzumab: mechanism of action, resistance and future perspectives in HER2-overexpressing breast cancer. Ann Oncol. 2007; 18:977-984. [PubMed: 17229773] 
14. Jacob JB, Kong YM, Nalbantoglu I, Snower DP, Wei WZ. Tumor regression following DNA vaccination and regulatory $\mathrm{T}$ cell depletion in neu transgenic mice leads to an increased risk for autoimmunity. J Immunol. 2009; 182:5873-5881. [PubMed: 19380836]

15. Radkevich-Brown O, Jacob J, Kershaw M, Wei WZ. Genetic regulation of the response to Her-2 DNA vaccination in human Her-2 transgenic mice. Cancer Res. 2009; 69:212-218. [PubMed: 19118005]

16. Miller S, McRae BL, Vanderlugt C, Nikcevich KM, Ope JG, Karpus WJ. Evolution of the T-cell repertoire during the course of experimental immune-mediated demyelinating disease. Immunol Rev. 1995; 144:225. [PubMed: 7590815]

17. Swanborg, RH.; Stepaniak, JA. Experimental autoimmune encephalomyelitis in the rat. In: JE, Coligan; AM, Kruisbeek; DH, Margulies, editors. Current protocols in immunology. New York: John Wiley \& Sons Inc; 1996. p. 15.2.1-15.2.4.

18. Myers LK, Rosloniec EF, Cremer MA, Kang AH. Collagen-induced arthritis, an animal model of autoimmunity. Life Sci. 1997; 61:1861-1878. [PubMed: 9364191]

19. Christadoss P, Lindstrom JM, Talal N, Duvic CR, Kalantri A, Shenoy M. Immune response gene control of lymphocyte proliferation induced by acetylcholine receptor-specific helper factor derived from lymphocytes of myasthenic mice. J Immunol. 1986; 137:1845-1849. [PubMed: 2943805]

20. Christadoss P, Poussin M, Deng C. Animal models of myasthenia gravis. Clin Immunol. 2000; 94:75-87. [PubMed: 10637092]

21. Bergman PJ, Camps-Palau MA, McKnight JA, et al. Development of a xenogeneic DNA vaccine program for canine malignant melanoma at the Animal Medical Center. Vaccine. 2006; 24:45824585. [PubMed: 16188351]

22. Kutzler MA, Weiner DB. DNA vaccines: ready for prime time? Nat Rev Genet. 2008; 9:776-788. [PubMed: 18781156]

23. Jacob J, Radkevich O, Forni G, et al. Activity of DNA vaccines encoding self or heterologous Her-2/neu in Her-2 or neu transgenic mice. Cell Immunol. 2006; 240:96-106. [PubMed: 16930573]

24. Whittington PJ, Piechocki MP, Heng HH, et al. DNA vaccination controls Her-2+ tumors that are refractory to targeted therapies. Cancer Res. 2008; 68:7502-7511. [PubMed: 18794138]

25. Piechocki MP, Ho YS, Pilon S, Wei WZ. Human ErbB-2 (Her-2) transgenic mice: a model system for testing Her-2 based vaccines. J Immunol. 2003; 171:5787-5794. [PubMed: 14634087]

26. Stancovski I, Hurwitz E, Leitner O, Ullrich A, Yarden Y, Sela M. Mechanistic aspects of the opposing effects of monoclonal antibodies to the ERBB2 receptor on tumor growth. Proc Natl Acad Sci U S A. 1991; 88:8691-8695. [PubMed: 1717984]

27. Bacus SS, Stancovski I, Huberman E, et al. Tumor-inhibitory monoclonal antibodies to the HER-2/ Neu receptor induce differentiation of human breast cancer cells. Cancer Res. 1992; 52:2580_ 2589. [PubMed: 1373672]

28. Cho HS, Mason K, Ramyar KX, et al. Structure of the extracellular region of HER2 alone and in complex with the Herceptin Fab. Nature. 2003; 421:756-760. [PubMed: 12610629]

29. Drebin JA, Stern DF, Link VC, Weinberg RA, Greene MI. Monoclonal antibodies identify a cellsurface antigen associated with an activated cellular oncogene. Nature. 1984; 312:545-548. [PubMed: 6504162]

30. Mahoney KH, Miller BE, Heppner GH. FACS quantitation of leucine aminopeptidase and acid phosphatase on tumor-associated macrophages from metastatic and nonmetastatic mouse mammary tumors. J Leukoc Biol. 1985; 38:573-585. [PubMed: 2413152]

31. Wei WZ, Shi WP, Galy A, et al. Protection against mammary tumor growth by vaccination with full-length, modified human ErbB-2 DNA. Int J Cancer. 1999; 81:748-754. [PubMed: 10328228]

32. Piechocki MP, Pilon SA, Wei WZ. Complementary antitumor immunity induced by plasmid DNA encoding secreted and cytoplasmic human ErbB-2. J Immunol. 2001; 167:3367-3374. [PubMed: 11544327]

33. King BL, Carter D, Foellmer HG, Kacinski BM. Neu proto-oncogene amplification and expression in ovarian adenocarcinoma cell lines. Am J Pathol. 1992; 140:23-31. [PubMed: 1346236] 
34. Jacob JB, Kong YM, Meroueh C, et al. Control of Her-2 tumor immunity and thyroid autoimmunity by MHC, regulatory T cells. Cancer Res. 2007; 67:7020-7027. [PubMed: 17638915]

35. Piechocki MP, Pilon SA, Wei WZ. Quantitative measurement of anti-ErbB-2 antibody by flow cytometry and ELISA. J Immunol Methods. 2002; 259:33-42. [PubMed: 11730839]

36. Rolla S, Marchini C, Malinarich S, et al. Protective immunity against neu-positive carcinomas elicited by electroporation of plasmids encoding decreasing fragments of rat neu extracellular domain. Hum Gene Ther. 2008; 19:229-240. [PubMed: 18269312] 


\section{A DNA vaccine constructs}

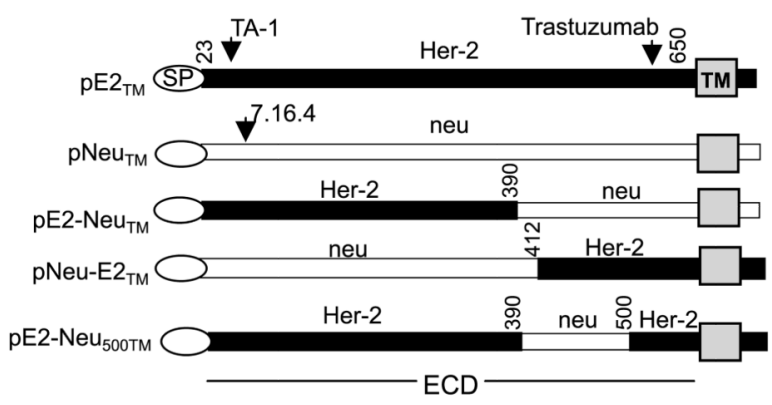

Her-2 sequence

Neu sequence

E2: Her-2, SP: signal peptide

TM: transmembrane domain

ECD: extracellular domain

Vertical values represent amino acid nos.

BALB Her-2 Tg mice vaccination scheme

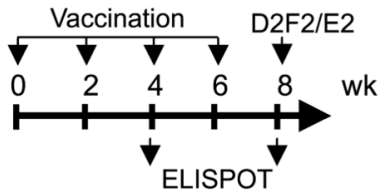

B Her-2 antibodies

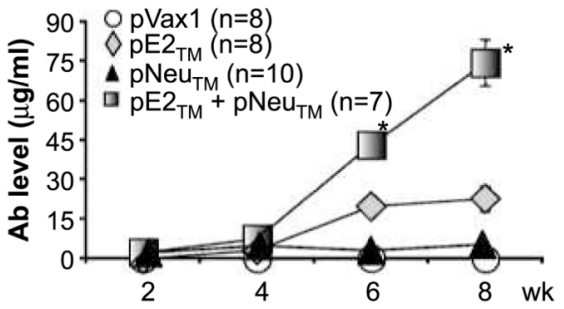

C IFN $-\gamma \quad 2 X$ vaccination

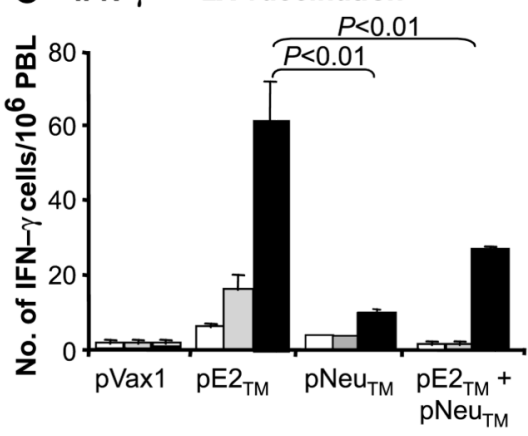

$4 \times$ vaccination

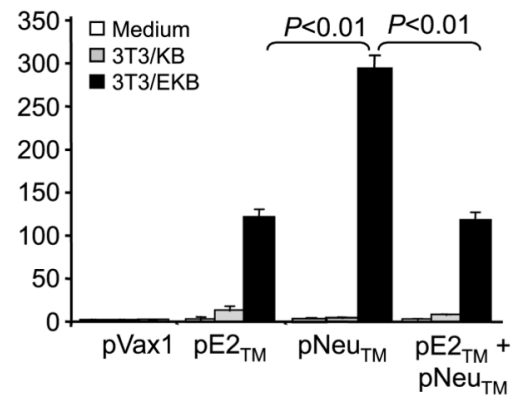

D Tumor growth inhibition

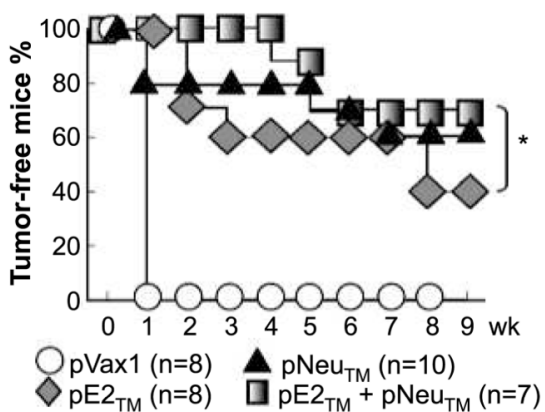

Figure 1.

$A$, Her-2 DNA vaccine constructs. $B$, cocktail vaccine in BALB Her-2 Tg mice. Mice were electrovaccinated four times, every 2 wk with $50 \mu \mathrm{g}$ of either $\mathrm{pE} 2{ }_{\mathrm{Tм}}$ or $\mathrm{pNeu}$ тм, or a cocktail of both at half the dosage. pGM-CSF $(50 \mu \mathrm{g})$ was included in each vaccine formulation. Control mice received pVax 1 and pGM-CSF. Sera were collected after each vaccination and Her-2-specific antibodies of individual mice were measured by flow cytometry. $C$, Her-2responsive IFN- $\gamma$-secreting T cells in pooled PBL were measured by ELISPOT assay after the second and fourth vaccinations. PBL were incubated with 3T3/EKB for $48 \mathrm{~h}$ before the assay and $3 \mathrm{~T} 3 / \mathrm{KB}$ cells were used as controls. $D$, at $2 \mathrm{wk}$ following the fourth vaccination, all mice were challenged s.c. with $2 \times 10^{5} \mathrm{D} 2 \mathrm{~F} 2 / \mathrm{E} 2$, and tumors were palpated weekly. There were 7 to 10 mice per group ( $*, P<0.05)$. 

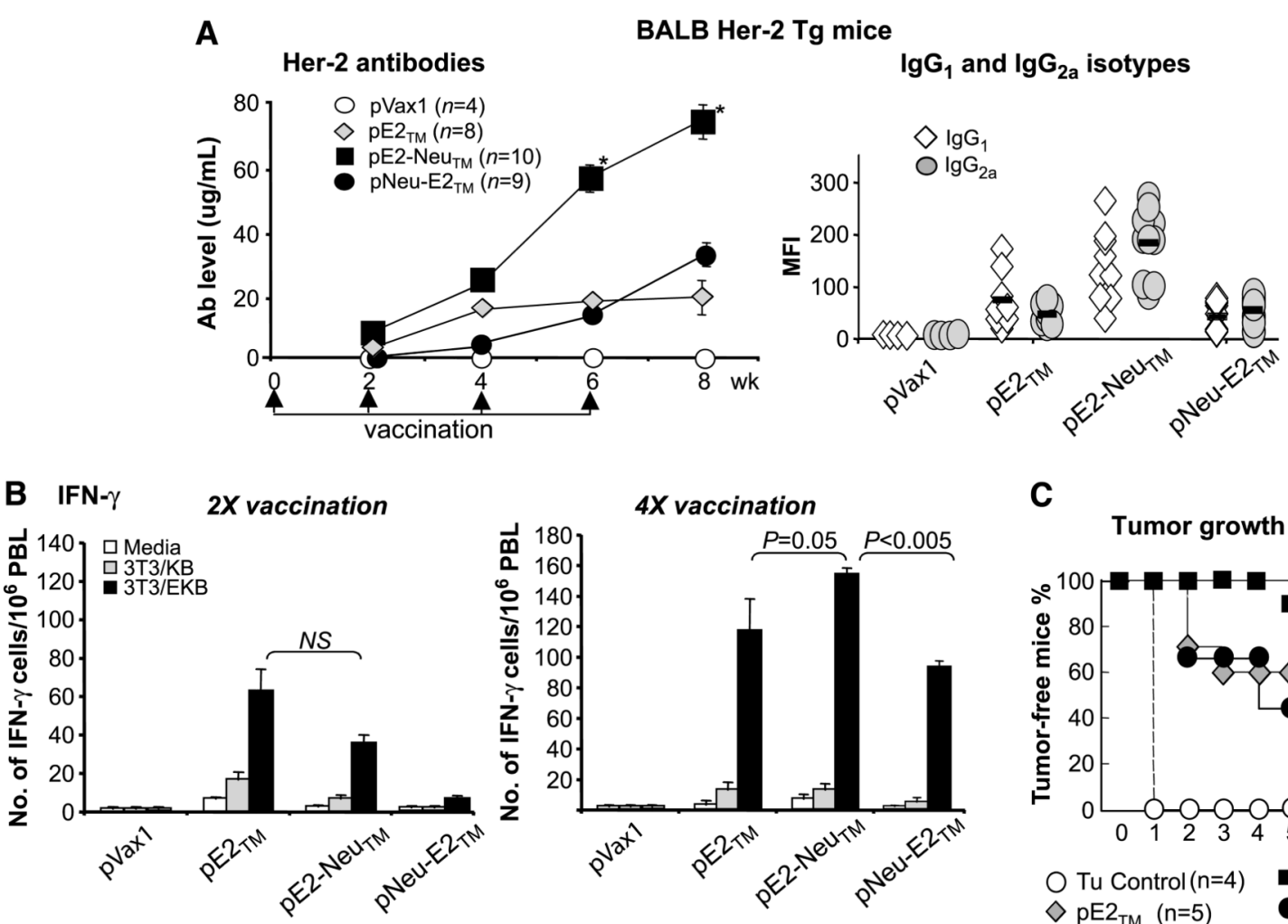

C

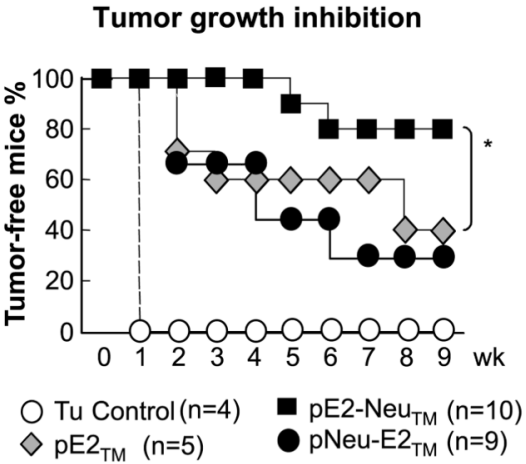

Figure 2.

Hybrid vaccines in BALB Her-2 Tg mice. $A$, mice were vaccinated four times with $\mathrm{pE} 2_{\mathrm{тм}}$, pE2-Nеuтм, or pNeu-E2тм. Her-2 antibodies in individual mice were measured after each vaccination. $\operatorname{IgG}_{1}$ and $\mathrm{IgG}_{2 \mathrm{a}}$ levels were analyzed after the last vaccination. $B$, Her-2reactive IFN- $\gamma$-secreting cells in pooled PBL were measured after the second and fourth vaccination. $C$, at $2 \mathrm{wk}$ following the last vaccination, mice were challenged with $2 \times 10^{5}$ D2F2/E2 and tumor growth was monitored by weekly palpation. There were 4 to 10 mice per group $(*, P<0.001)$. 


\section{A (BALBXB6) F1 Her-2 Tg mice experimental design}

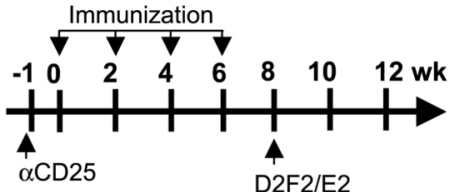

B

Her-2 antibodies
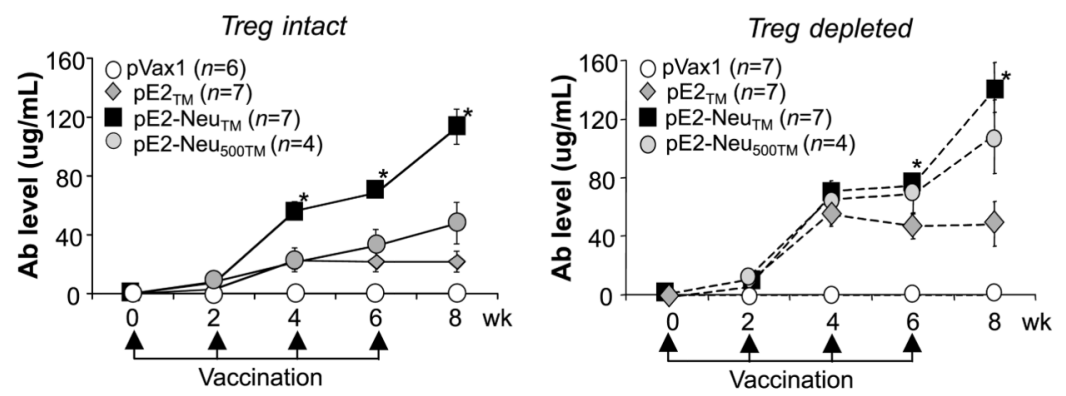

C

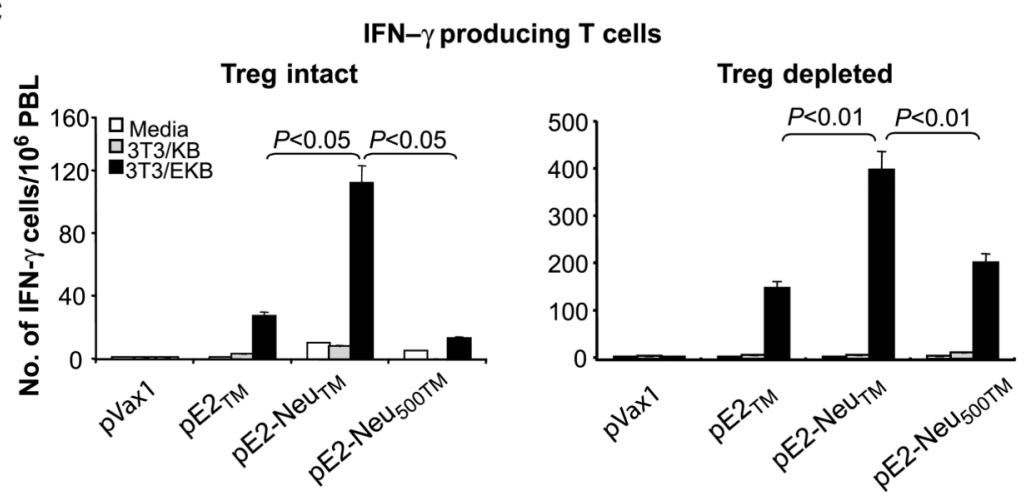

D

Tumor growth inhibition
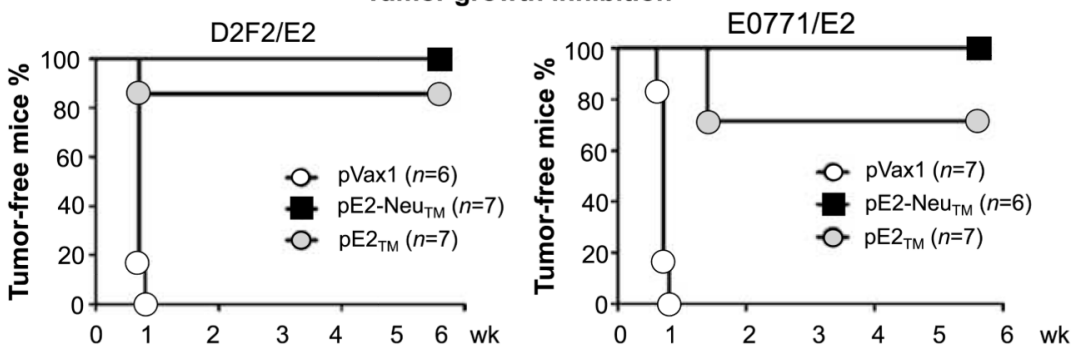

Figure 3.

Hybrid vaccines in $(\mathrm{BALB} \times \mathrm{B} 6) \mathrm{F} 1 \mathrm{Her}-2 \mathrm{Tg}$ mice. $A$, mice were electrovaccinated four times with $\mathrm{pE} 2_{\mathrm{Tм}}, \mathrm{pE} 2-\mathrm{Neu}$ тм, or $\mathrm{pE} 2-\mathrm{Neu}_{500^{\mathrm{Tм}}}$ with or without Treg depletion by CD25 $\mathrm{mAb} . B$, Her-2 antibodies in individual mice were measured after each vaccination. $C$, IFN$\gamma$-secreting T cells in pooled PBL were measured after four vaccinations. $D$, in a repeat experiment, vaccinated mice were challenged with $2 \times 10^{5}$ D2F2/E2 or E0771/E2 s.c. and tumor growth was monitored weekly. There were six to seven mice per group $(*, P<0.01)$. 
B6 Her-2 Tg mice
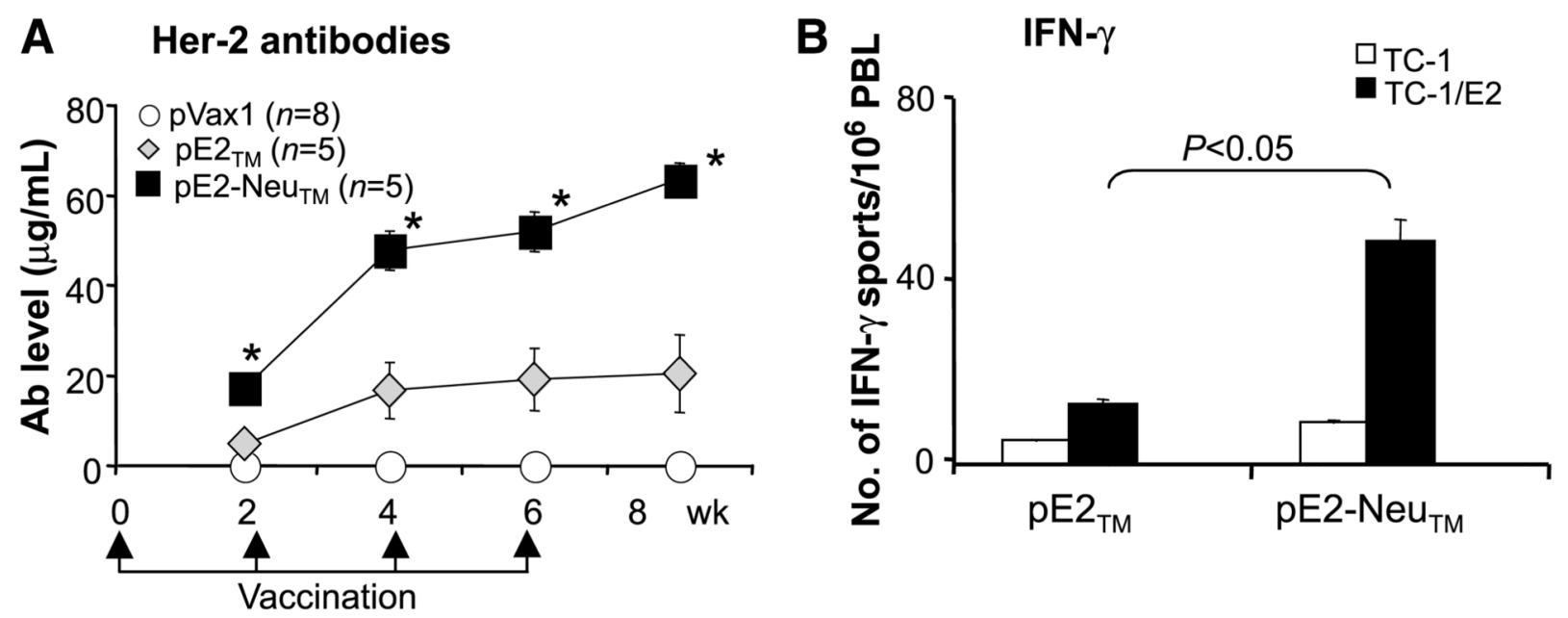

C

Tumor growth inhibition E0771/E2

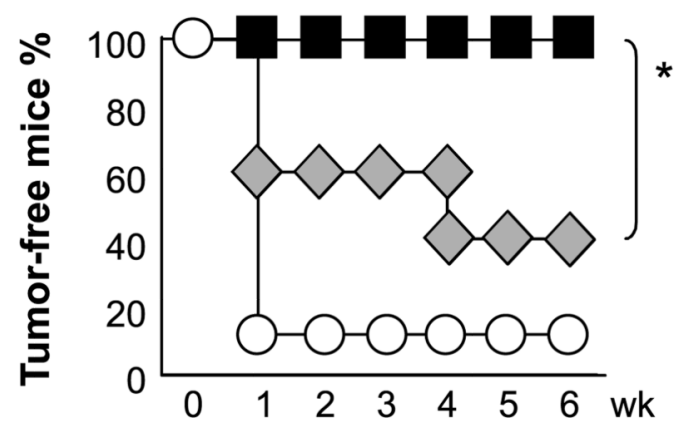

$\bigcirc \mathrm{pVax} 1(n=8) \quad \square \mathrm{pE} 2-\mathrm{Neu}_{\mathrm{TM}}(n=5)$
$\diamond \mathrm{pE} 2_{\mathrm{TM}}(n=5)$

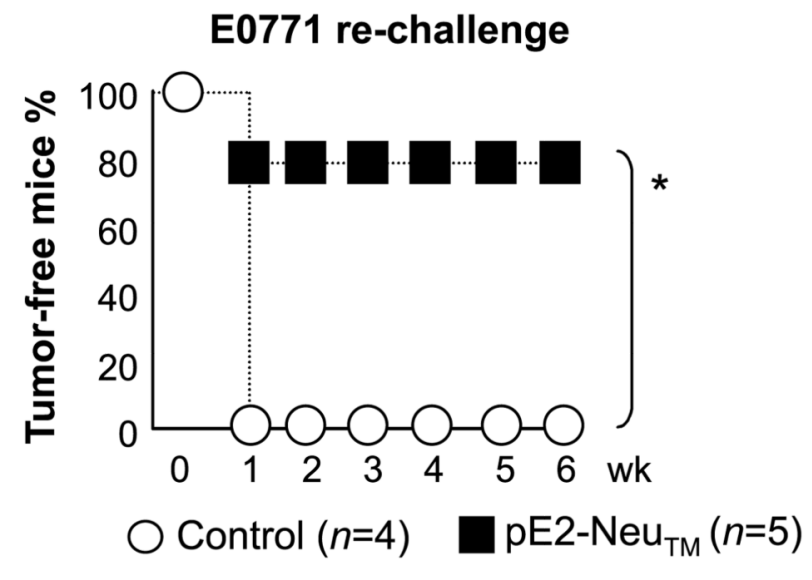

Figure 4.

Hybrid vaccines in B6 Her-2 Tg mice. A, B6 Her-2 Tg mice were depleted of Treg 1 wk prior to the first vaccination. Her-2 antibodies of individual mice were measured after each vaccination. $B$, Her-2-reactive T cells in pooled PBL were monitored by ELISPOT

following the last vaccination and after $48 \mathrm{~h}$ of stimulation with TC-1/ E2 cells; TC-1 cells were used as controls. $C$, at $2 \mathrm{wk}$ after the final vaccination, mice were challenged with $2 \times$ $10^{5} \mathrm{E} 0771 / \mathrm{E} 2$. Tumors were monitored by weekly palpation. There were five to eight mice per group. Tumor-free mice were re-challenged with the parental tumor line, E0771 ( ${ }^{*}, P<$ 0.01). 
A

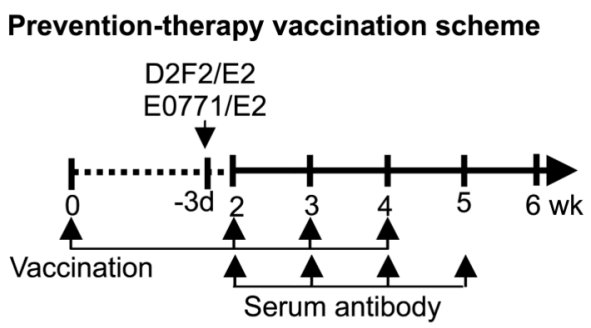

B

BALB Her-2 Tg mice

Her-2 antibodies

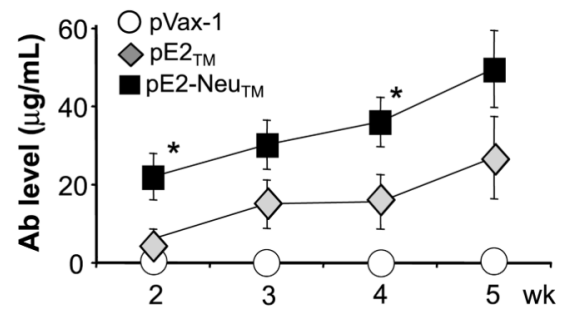

D2F2/E2 tumor growth inhibition

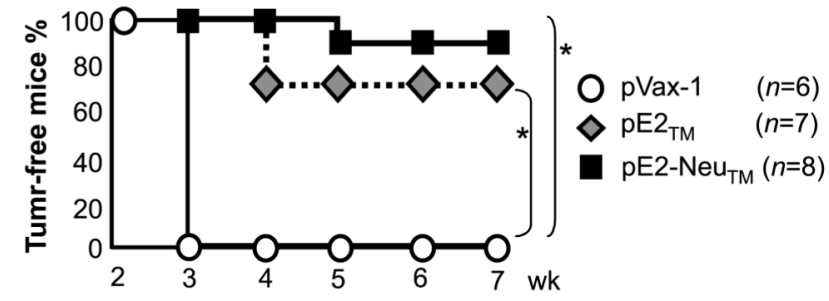

C

Her-2 expression in D2F2/E2 tumor outgrowth

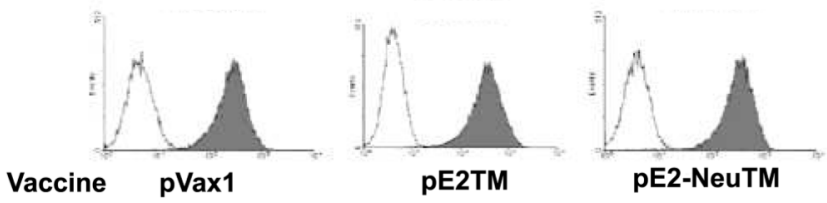

D

\section{Her-2 antibodies}

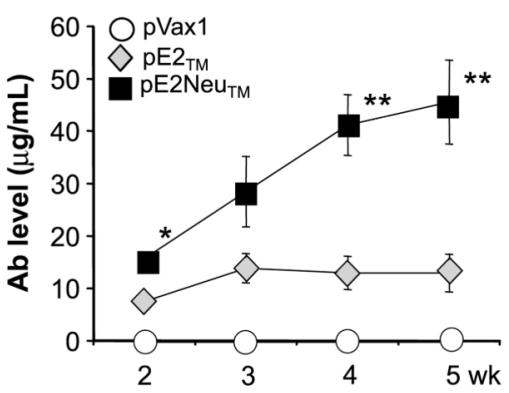

B6 Her-2 Tg mice

\section{E0771/E2 tumor growth inhibition}

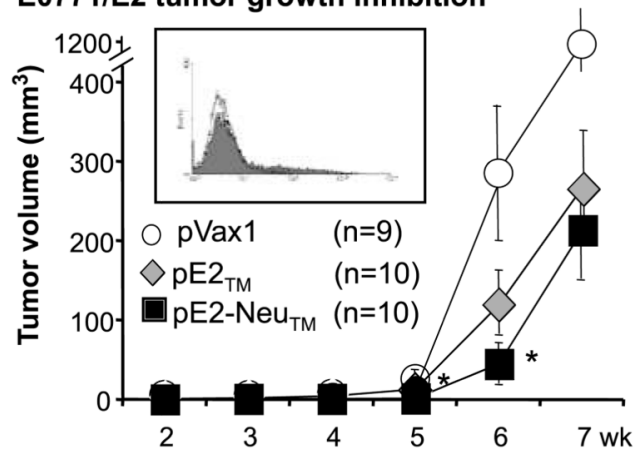

Figure 5.

The efficacy of one preventive and three therapeutic vaccines. A, BALB Her-2 Tg mice received $2 \times 10^{5} \mathrm{D} 2 \mathrm{~F} 2 / \mathrm{E} 2$ tumors $11 \mathrm{~d}$ after a single protective vaccination. Mice then received three weekly vaccinations, starting $3 \mathrm{~d}$ after tumor inoculation. $B$, Her-2 antibodies were measured after each vaccination and tumor growth was monitored weekly. There were six to eight mice per group. $C$, expression of Her-2 by primary cultures of D2F2/E2 tumor was measured by mAb TA-1. $D$, B6 Her- 2 Tg mice were inoculated with $2 \times 10^{5}$ E0771/E2 tumor cells following the same vaccination scheme, except that CD25 mAb was given $1 \mathrm{wk}$ 
before the first vaccination. Inset, Her-2 expression on E0771/E2 tumor outgrowth in pVax1 group. There were 9 to 10 mice per group (*, $P<0.05$; **, $P<0.01$ ). 
Table 1

Induction of Her-2 or neu immunity with self vs. heterologous DNA vaccination

\begin{tabular}{|c|c|c|c|c|}
\hline & \multicolumn{2}{|c|}{ pNeuтм vaccinated } & \multicolumn{2}{|c|}{ pE2 $2_{\mathrm{TM}}$ vaccinated } \\
\hline & BALB NeuT mice & BALB Her-2 Tg mice & BALB NeuT mice & BALB Her-2 Tg mice \\
\hline \multicolumn{5}{|l|}{ Antibodies $(\mu \mathrm{g} / \mathrm{mL})$} \\
\hline Anti-Neu antibodies & $16 \pm 2^{*}$ & $54 \pm 5^{*}$ & $0.3 \pm 0.2$ & 0 \\
\hline Anti-Her-2 antibodies & $0^{*}$ & $4 \pm 3^{*}$ & $40 \pm 3$ & $20 \pm 5$ \\
\hline \multicolumn{5}{|c|}{ IFN- $\gamma$ T cells (spots $/ 10^{6}$ cells) } \\
\hline Neu antigen & $294 \pm 50^{\dagger}$ & $237 \pm 18$ & $567 \pm 176$ & $10 \pm 2$ \\
\hline Her-2 antigen & $22 \pm 4$ & $292 \pm 16^{*}$ & $1,014 \pm 126$ & $124 \pm 4$ \\
\hline
\end{tabular}

